\title{
Euroroundup
}

\section{UPDATE OF CLOSTRIDIUM DIFFICILE-ASSOCIATED DISEASE DUE TO PCR RIBOTYPE 027 IN EUROPE}

\author{
EJ Kuijper (e.j.kuijper@lumc.nl)1, B Coignard², J Brazier ${ }^{3}$, C Suetens ${ }^{4}$, D Drudy5 , C Wiuff6, H Pituch, P Reichert ${ }^{8}$, F \\ Schneider ${ }^{9}$, AF Widmer ${ }^{10}$, \\ KE Olsen ${ }^{11}, \mathrm{~F}$ Allerberger ${ }^{12}$, DW Notermans ${ }^{13}$, F Barbut ${ }^{14}$, M Delmée ${ }^{15}$, M Wilcox ${ }^{16}$, A Pearson ${ }^{17}$, BC Patel ${ }^{17}$, DJ Brown ${ }^{18}$, R Frei ${ }^{19}$, \\ T Åkerlund ${ }^{20}$, \\ IR Poxton ${ }^{21}, \mathrm{P}$ Tüll22
}

1. National Reference Laboratory for Clostridium difficile, Leiden University Medical Centre, Leiden, The Netherlands

2. Department of infectious diseases, Institut de Veille Sanitaire (French National Institute of Health, InVS), Saint-Maurice, France

3. Anaerobe Reference Laboratory, National Public Health Service for Wales, University Hospital of Wales, Cardiff, United Kingdom

4. Epidemiology Unit, Scientific Institute of Public Health (IPH), Brussels, Belgium

5. Centre for Food Safety, Food Science and Veterinary Medicine, University College Dublin, Dublin, Ireland

6. Health Protection Scotland, Section for Healthcare-Associated Infection and Infection Control, Glasgow, United Kingdom

7. Department of Medical Microbiology, University of Warsaw, Poland

8. National Health Laboratory (Laboratoire National de Santé, LNS), Luxembourg

9. Microbiology division, Rue du Laboratoire, Luxembourg

10. Division of Infectious diseases and Hospital Epidemiology, University Hospital, Basel, Switzerland

11. National Reference Laboratory for Enteropathogens, Statens Serum Institute (Danish National Institute of Public Health, SSI), Copenhagen, Denmark

12. Österreichische Agentur für Gesundheit und Ernährungssicherheit (Austrian Agency for Health and Food Safety, AGES), Vienna, Austria 13. Centrum Infectieziektebestrijding (Centre for Infectious Disease Control, CIb), Rijksinstituut voor Volksgezondheid en Milieu (National Intitute for Public Health and the Environment, RIVM), Bilthoven, The Netherlands

14. National Reference Center for Clostridium difficile, Saint-Antoine Hospital, Paris, France

15. Microbiology Department, University hospital Saint-Luc, Brussels, Belgium

16. Clostridium difficile Ribotyping Network for England (CDRNE), Microbiology, Leeds General Infirmary, Leeds, United Kingdom

17. Health Protection Agency (HPA), London, United Kingdom

18. National Health Service (NHS), Glasgow, United Kingdom

19. Microbiology Laboratory, University Hospital, Basel, Switzerland

20. Smittskyddsinstitutet (Swedish Institute for Infectious Disease Control, SMI), Solna, Sweden

21. Medical Microbiology, Centre for Infectious Diseases, University of Edinburgh College of Medicine and Veterinary Medicine, Edinburgh, Scotland

22 European Centre for Disease Prevention and Control (ECDC), Solna, Sweden

Recent outbreaks of Clostridium difficile-associated diarrhoea

(CDAD) with increased severity, high relapse rate and significant mortality have been related to the emergence of a new, hypervirulent C. difficile strain in North America, Japan and Europe. Definitions have been proposed by the European Centre of Disease Prevention and Control (ECDC) to identify severe cases of CDAD and to differentiate community-acquired cases from nosocomial CDAD (http://www.ecdc.europa.eu/documents/pdf/Cl_dif_v2.pdf). CDAD is mainly known as a healthcare-associated disease, but it is also increasingly recognised as a community-associated disease. The emerging strain is referred to as North American pulsed-field type 1 (NAP1) and PCR ribotype 027. Since 2005, individual countries have developed surveillance studies to monitor the spread of this strain. C. difficile type 027 has caused outbreaks in England and Wales, Ireland, the Netherlands, Belgium, Luxembourg, and France, and has also been detected in Austria, Scotland, Switzerland, Poland and Denmark. Preliminary data indicated that type 027 was already present in historical isolates collected in Sweden between 1997 and 2001.

Introduction

A highly virulent variant of Clostridium difficile is emerging throughout Europe. This strain is characterised as toxinotype III, North American pulsed field gel electrophoresis type 1 (NAP1), restriction endonuclease analysis group $\mathrm{BI}$ and $\mathrm{PCR}$ ribotype 027 $[1,2,3]$. The type 027 strain carries the binary toxin gene, has an $18 \mathrm{bp}$ deletion in the regulatory gene $t c d C$, and a $1 \mathrm{bp}$ deletion at position 117 of $t c d C$, resulting in a frameshift mutation that potentially allows for larger amounts of toxins to be produced. It is assumed that the increased virulence of this strain is associated with higher amounts of toxin production [4]. Clinical response rates are reduced following treatment with metronidazole or vancomycin $[5,6]$. This 027 type strain was first isolated in 1988 in France and is considered a 'historical isolate', since it was susceptible to fluoroquinonoles and erythromycin [7]. It only accounted for sporadic cases of $C$. difficile-associated disease (CDAD) until 2002. It has been suggested that the recent acquisition of resistance to the newer fluoroquinolones by the 027 strain was the major reason for its wide dissemination [1,2] although this phenotype is not uncommon in other $C$. difficile strains [8]. Alternatively, increased virulence resulting in pronounced diarrhoeal symptoms may have promoted spread and cross-infection within healthcare institutions. Since 2002, it had caused major epidemics of CDAD in hospitals in Canada and also in the United States [1,2,3].

\section{Background}

CDAD occurs most often in people whose normal gut flora has been disturbed, for example during antibiotic treatment. The 
clinical manifestation of CDAD can range from diarrhoea to severe pseudomembranous colitis, with a mortality of up to $30 \%$ [1]. CDAD is mainly known as a healthcare-associated disease, but it is increasingly recognised as a community-associated disease. At the 17th European Congress for Microbiology and Infectious Disease (31 March-3 April 2007) in Munich, results of a German pilot study were presented. It revealed a high CDAD incidence of $9.3 \%$ among 703 patients with diarrhoea visiting general practitioners in the period from August to December 2006 in Germany. Salmonella enteritica was cultured in $4.8 \%$ and Campylobacter in $3 \%$ of those patients [9].

The diagnostic methods routinely employed in different European laboratories today are not standardised and vary significantly $[1,10]$. Most laboratories prefer to detect $C$. difficile specific toxins in faeces. Faeces toxin detection can be performed either by cell cytotoxicity assay or immunological detection. The former is the gold standard, but requires up to two days. Various enzyme-immunoassays are available for immunological detection of $C$. difficile toxins, but their sensitivity and specificity varies enormously. Therefore, a study funded by the European Union (EU) has been launched in order to improve diagnostics of CDAD (LSHE-CT-2006-037870: European approach to combat outbreaks of CDAD by development of new diagnostic tests).

\section{Surveillance efforts}

The European Study Group for Clostridium difficile (ESGCD) performed a two-month surveillance study in 2005 on the prevalence of CDAD due to $C$. difficile 027 in $12 \mathrm{EU}$ member states [11]. Based on these data and the recently published background document supported by the ECDC, individual countries have developed surveillance studies to the spread of type 027 in their country [1]. C. difficile type 027 causes outbreaks in the United Kingdom (UK) (since 2003 [12]), the Netherlands (since 2003 [13,14]), Belgium (since 2003 [15,16]), France (since $2006[17,18]$ ), and has also been detected in Austria (2006 [19]), Japan (2005 [20]) and Ireland [21]. In addition, it has been found in Switzerland (AF Widmer, R Frei, M Rupnik, personal communication), Luxembourg (P Reichert, E Kuijper, personal communication), Poland (H Pituch, E Kuijper, personal communication), and Denmark [22] (Figure). Preliminary data presented at the 2nd International Clostridium difficile symposium in Maribor, Slovenia (6-9 June, 2007) indicated that type 027 was present in three of more than 1,500 historical isolates collected in Sweden between 1997 and 2001. These strains were sensitive to fluoroquinolones and resemble the pre-outbreak type 027 strains in the United States [2] and France [7].

In England, a mandatory surveillance programme of CDAD in people aged 65 years and over has been included in the healthcareassociated infection surveillance system for acute hospital trusts (UK hospitals are managed by acute trusts; for a detailed definition see: http://www.info.doh.gov.uk/nhsfactsheets.nsf/vwHelp/Acute $\% 20$ trusts? OpenDocument) since January 2004. Some 55,681 cases were reported in 2006 . This represents an $8 \%$ increase in CDAD cases from 2005 to 2006, after a 17\% increase from 2004 to 2005. The mandatory surveillance is operated by the Health Protection Agency (HPA) on behalf of the Department of Health (DH). Epidemiological data are collected quarterly from each of the 169 acute National Health Service (NHS) trusts that treat adult patients and yearly reports are produced by the HPA [23]. CDAD incidence rates of individual trusts are publicly reported each year by the $\mathrm{DH}$ [24]. Through its network of regional laboratories
F I G U R E

Distribution of $C$. difficile ribotype 027 in Europe ${ }^{\star}$ as of June 2007

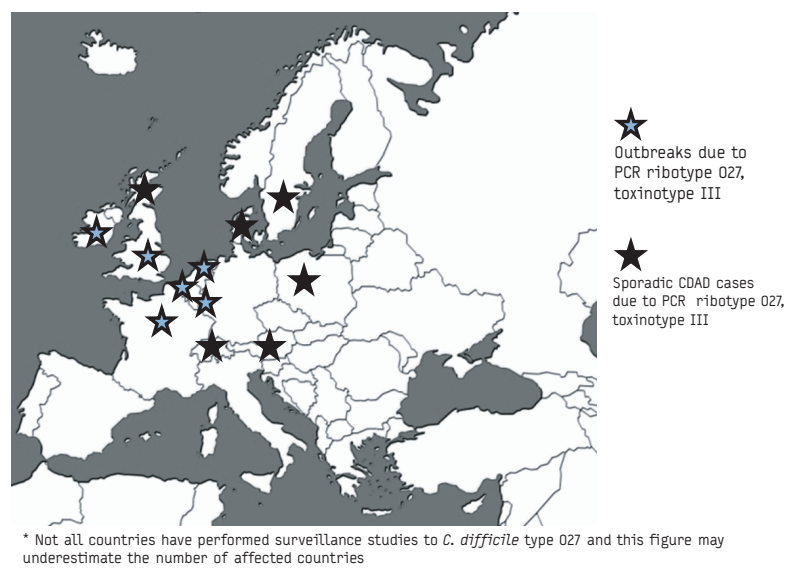

in collaboration with the Anaerobe Reference Laboratory (ARL) in Cardiff, the HPA obtained further isolates of $C$. difficile from symptomatic patients in a structured but random sampling scheme. In an allocated week, local hospitals within each of the nine HPA regions were asked to submit a maximum of $10 \mathrm{C}$. difficile toxinpositive stools to their regional HPA laboratory to culture $C$. difficile. Isolates of putative $C$. difficile were then forwarded to the ARL for confirmation of identity, susceptibility testing against eight antimicrobial agents and typing by the PCR ribotyping method. The findings have recently been published in Eurosurveillance [25]. A laboratory surveillance network in England was established in 2007 to facilitate the early investigation of clusters of CDAD, particularly those associated with severe symptoms.

In October 2005, the National Institute for Public Health and the Environment (RIVM) in the Netherlands published specific CDAD ribotype 027 guidelines for infection control and treatment to be used by hospitals and nursing homes in response to the outbreaks in the Netherlands. Diagnostic facilities were increased and made accessible for hospital microbiologists. All laboratories were recommended to culture $C$. difficile from toxin positive faeces samples and to store the isolates. Microbiologists were requested to send strains to the national Reference laboratory from patients with a severe course of CDAD or when an increased incidence of CDAD was noticed. A National Reference Laboratory for $C$. difficile was established at the Department of Medical Microbiology at the Leiden University Medical Center. Strains were characterised by PCR ribotyping, toxinotyping, presence of toxin genes and antimicrobial susceptibility [26]. The results of the first year of surveillance are currently in press [27].

Recommendations for diagnosis, early warning and surveillance of CDAD in France were issued by the French Institute for Public Health (InVS) and the national reference laboratory for $C$. difficile (Hôpital Saint-Antoine, Paris) in May 2006. Hospitals and nursing homes were requested to notify severe cases or clusters of CDAD, which were systematically investigated by local health departments and regional infection control coordinating centres. Culture of faeces was promoted as the diagnostic method of choice for such cases, and a network of six regional laboratories was set up in order 
to facilitate characterisation of $C$. difficile strains. The Ministry of Health disseminated recommendations for CDAD prevention and control to all hospitals and nursing homes in September 2006. A national, prospective surveillance of CDAD incidence among hospitals will be implemented in 2007 and will include a sampling scheme in order to better assess the geographical dissemination of $C$. difficile strains.

One case of $C$. difficile 027 was identified in Scotland in 2006 by the UK national reference laboratory in Cardiff. A research study in Western Scotland examined 102 additional strains obtained from nine hospitals from 2006 to 2007 . None of these were ribotype 027. Mandatory surveillance in line with the English system has been initiated in Scotland in 2006. Data on the incidence of $C$. difficile 027 in people aged 65 years or older are being collected in healthcare institutions in Scotland and will be published in the public domain by the end of 2007.
In Belgium, the Scientific Institute of Public Health (IPH) and the national reference laboratory (Université catholique de Louvain) set up a laboratory-based surveillance of CDAD clusters in January 2006. Laboratories are requested to send in strains, when two or more CDAD cases occur in the same department within a period of one month. In parallel, a prospective surveillance of CDAD incidence was set up in Belgian acute care hospitals in collaboration with the Belgian Infection Control Society (BICS). Hospitals report clinical and risk factor data on all CDAD cases as well as denominator data on a web-based data entry form during a six month surveillance period. Hospitals are also requested to send strains of five consecutive CDAD patients to the reference laboratory for species confirmation, detection of the $t c d C$ deletion and the binary toxin, toxinotyping, PCR ribotyping and determination of antimicrobial susceptibility. National guidelines for prevention and control of CDAD in hospitals and nursing homes were issued by the BICS in June 2006.

T A B L E

C. difficile type 027 in 11 European countries (due to differences in surveillance the data cannot be directly compared).

\begin{tabular}{|c|c|c|c|c|c|c|c|}
\hline Country & $\begin{array}{l}\text { Survey } \\
\text { period }\end{array}$ & $\begin{array}{c}\text { Total number of } \\
\text { inhabitants / hospitals } / \\
\text { hospital beds }\end{array}$ & $\begin{array}{c}\text { Number of } \\
\text { hospitals positive } \\
\text { for } 027 \text { / number } \\
\text { of hospitals } \\
\text { investigated for } \\
027\end{array}$ & $\begin{array}{l}\text { Number of } \\
\text { nursing } \\
\text { homes } \\
\text { positive for } \\
027\end{array}$ & $\begin{array}{c}\text { Number } \\
\text { of } 027 \\
\text { strains } \\
\text { / Total } \\
\text { number } \\
\text { of strains } \\
\text { tested } \\
\end{array}$ & $\begin{array}{l}\text { Mortality } \\
\text { attributable } \\
\text { to CDAD }\end{array}$ & Updates available at: \\
\hline $\begin{array}{l}\text { England } \\
\text { and Wales }\end{array}$ & $\begin{array}{l}2005- \\
2006\end{array}$ & $\begin{array}{c}53.4 \text { million inhab/ } \\
\text { England: } 172 \text { acute trust } \\
\text { hosp/135,794 beds; Wales: } \\
95 / 11,500\end{array}$ & $94 / 170(55.3 \%)$ & n.a & $971 / \mathrm{n} \cdot \mathrm{a}$ & n.a & $\begin{array}{l}\text { http://www.hpa.org.uk/infections/ } \\
\text { topics_az/clostridium_difficile/ } \\
\text { default.htm }\end{array}$ \\
\hline Scotland & $\begin{array}{l}2006- \\
2007\end{array}$ & $\begin{array}{l}5.1 \text { million/ } \\
261 \text { (incl. } 45 \text { acute hosp)/ } \\
29,000\end{array}$ & $1 / 9(11 \%)$ & 0 & $1 / 103(1 \%)$ & n.a & $\begin{array}{l}\text { http://www.hps.scot.nhs.uk/haiic/ } \\
\text { sshaip/clostridiumdifficile.aspx }\end{array}$ \\
\hline Ireland & 2006 & 4.2 million/61/10,000 & $7 / 7(100 \%)$ & 2 & $\begin{array}{l}81 / 350 \\
(23.1 \%)\end{array}$ & n.a & $\begin{array}{l}\text { http://www.ndsc.ie/hpsc/A-Z/ } \\
\text { Gastroenteric/CDifficile }\end{array}$ \\
\hline France & $\begin{array}{l}\text { Jan2006 } \\
- \text { April } \\
2007\end{array}$ & $\begin{array}{l}64 \text { million/ca. 2,800/ca. } \\
\text { 460,000 }\end{array}$ & $40 / 164(24.3 \%)$ & 4 & $\begin{array}{l}277 / 471 \\
(58.8 \%)\end{array}$ & $\begin{array}{l}4 \% \text { (Northern } \\
\text { France only) }\end{array}$ & http://www.invs.sante.fr/raisin \\
\hline $\begin{array}{l}\text { The } \\
\text { Netherlands }\end{array}$ & $\begin{array}{l}2005- \\
2006\end{array}$ & 16.4 million/129/53,000 & $20 / 50(40 \%)$ & 7 & $\begin{array}{l}218 / 863 \\
(25.2 \%)\end{array}$ & $6.3 \%$ & $\begin{array}{l}\text { http://www.rivm.nl/cib/ } \\
\text { infectieziekten/Clostridium__a } \\
\text { difficile/Clostridium_difficile__ } \\
\text { draaiboek.jsp }\end{array}$ \\
\hline Belgium & $\begin{array}{l}2005^{-} \\
2006\end{array}$ & 10 million/113/51,640 & $38 / 78(48.7 \%)$ & n.a & $\begin{array}{c}190 / 814 \\
(23 \%)\end{array}$ & n.a & $\begin{array}{l}\text { http://www. } \\
\text { belgianinfectioncontrolsociety.be }\end{array}$ \\
\hline Poland & 2005 & 38 million/781/184,000 & $1 / 1(100 \%)$ & n.a & $1 / 175(0.6 \%)$ & na & \\
\hline Austria & 2006 & $\begin{array}{l}8.2 \text { million/ } \\
264 / \\
63,248\end{array}$ & $1 / 20(5 \%)$ & n.a & $1 / 102(1 \%)$ & n.a & \\
\hline Luxembourg & 2006 & 0.45 million/10/2100 & $4 / 10(40 \%)$ & n.a & $18 / 75(24 \%)$ & n.a & \\
\hline Switzerland & $\begin{array}{l}2005- \\
2006\end{array}$ & 7.3 million/337/28,080 & $3 / 11(27 \%)$ & 1 & $\begin{array}{l}4 / 231 \\
(1.7 \%)\end{array}$ & $0 \%$ & \\
\hline Denmark & $\begin{array}{l}\text { Nov } \\
2006- \\
\text { March } \\
2007\end{array}$ & 5.4 million/ 69/22.604 & n.a & n.a & $\begin{array}{l}6 \text { (pilot } \\
\text { study) }\end{array}$ & $\begin{array}{l}\text { Study in } \\
\text { progress }\end{array}$ & \\
\hline
\end{tabular}

n.a: data not available. 
The available results from the surveillance efforts of 11 European countries are summarised in the Table. As methodology, time period and geographical coverage of surveillance differ significantly from one country to another, these results are qualitative and cannot be used for purposes of comparison. A new surveillance study among all European member states, planned for 2007-2008, is currently being developed by ECDC in collaboration with ESGCD, a study group for Clostridium difficile set up by the European Society of Clinical Microbiology and Infectious Diseases (ESCMID). In addition, a specific surveillance programme (CDAD-KISS) has recently been launched in Germany.

\section{Conclusion}

C. difficile type 027 has been detected in an increasing number of European countries. This could either be due to the fact that more countries have started surveillance surveys or an indication that type 027 is spreading rapidly. As yet, type 027 has affected healthcare facilities in $11 \mathrm{EU}$ member states and in Switzerland (Figure). Increased awareness is necessary in all member states and surveillance studies should be performed with uniform definitions, as proposed by ECDC [1]. A guidance document for infection control measures has recently been prepared by international experts together with ECDC [28]. It is unknown how many CDAD cases in nursing homes and the community are due to type 027 . The situation in those settings warrants more attention in the future.

\section{References}

1. Kuijper EJ, Coignard B, Tüll P; ESCMID Study Group for Clostridium difficile; EU Member States; European Centre for Disease Prevention and Control. Emergence of Clostridium difficile-associated disease in North America and Europe. Clin Microbiol Infect. 2006;12 Suppl 6:2-18.

2. McDonald LC, Killgore GE, Thompson A, Owens RC, Kazakova SV, Sambol SP, et al. An epidemic, toxin gene-variant strain of Clostridium difficile. $N$ Engl J Med. 2005;353(23):2433-41.

3. Loo VG, Poirier L, Miller MA, Oughton M, Libman MD, Michaud S, et al. A predominantly clonal multi-institutional outbreak of Clostridium difficileassociated diarrhea with high morbidity and mortality. N Engl J Med. 2005;353(23):2442-9.

4. Warny M, Pepin J, Fang A, Killgore G, Thompson A, Brazier J, et al. Toxin production by an emerging strain of Clostridium difficile associated with outbreaks of severe disease in North America and Europe. Lancet. 2005;366(9491):1079-84.

5. Pepin J, Alary ME, Valiquette L, Raiche E, Ruel J, Fulop K, et al. Increasing risk of relapse after treatment of Clostridium difficile colitis in Québec, Canada. Clin Infect Dis. 2005;40(11):1591-7.

6. Pepin J, Valiquette L, Gagnon S, Routhier S, Brazeau I. Outcomes of Clostridium difficile-associated disease treated with metronidazole or vancomycin before and after the Emergence of NAP1/027. Am J Gastroenterol 2007. In press.

7. Popoff M, Rubin EJ, Gill DM, Boquet P. Actin-Specific ADP-Ribosyltransferase Produced by a Clostridium difficile Strain. Infect Immun. 1988;56(9):2299306.

8. Wilcox MH, Fawley W, Freeman J, Brayson J..In vitro activity of new generation fluoroquinolones against genotypically distinct and indistinguishable Clostridium difficile isolates. J Antimicrob Chemother. 2000;46(4):551-6.

9. Weil HP, Fischer-Brügge U, Harmanus C, Mattner F, Gastmeier P, Kuijper EJ. High incidence of Clostridium difficile-associated diarrhoea with a community onset in a hyperendemic region in Germany: 17th European Congress of Clinical Microbiology and Infectious Diseases, Munich, 31 March - 3 April 2007. Abstract \#0329.

10. Barbut F, Delmée M, Brazier JS, Petit JC, Poxton IR, Rupnik M, et al. A European survey of diagnostic methods and testing protocols for Clostridium difficile. Clin Microbiol Infect. 2003;9(10):989-96.

11. F. Barbut, P. Mastrantonio, M. Delmée, J. Brazier, G. Ackermann, E. Bouza, et al. for the European Study Group on Clostridium difficile (ESGCD). Prospective study of Clostridium difficile infections in Europe with phenotypic and genotypic characterization of the isolates. Submitted.
12. Smith A. Outbreak of Clostridium difficile infection in an English hospital linked to hypertoxin-producing strains in Canada and the US. Euro Surveill 2005;10(6):E050630.2. Available from: http://www.eurosurveillance.org/ ew/2005/050630.asp\#2

13. van Steenbergen J, Debast S, van Kregten E, van den Berg R, Notermans D, Kuijper E. Isolation of Clostridium difficile ribotype 027, toxinotype III in the Netherlands after increase in C. difficile-associated diarrhoea. Euro Surveill 2005:10(7):E050714.1. Available from: http://www.eurosurveillance. org/ew/2005/050714.asp\#1

14. van den Hof S, van der Kooi T, van den Berg R, Kuijper E, Notermans D. Clostridium difficile PCR ribotype 027 outbreaks in the Netherlands: recent surveillance data indicate that outbreaks are not easily controlled but interhospital transmission is limited. Euro Surveill 2006:11(1):E060126.2 Available from: http://www.eurosurveillance.org/ew/2006/060126.asp\#2

15. Joseph R, Demeyer D, Vanrenterghem D, van den Berg R, Kuijper E, Delmée M. First isolation of Clostridium difficile PCR ribotype 027, toxinotype II in Belgium. Euro Surveill 2005:10(10):E051020.4. Available from: http://www. eurosurveillance.org/ew/2005/051020.asp\#4

16. Delmée M, Ramboer I, Van Broeck J, Suetens C. Epidemiology of Clostridium difficile toxinotype III, PCR-ribotype 027 associated disease in Belgium, 2006. Euro Surveill 2006;11(9):E060914.2. Available from: http://www. eurosurveillance.org/ew/2006/060914.asp\#2

17. Tachon M, Cattoen C, Blanckaert K, Poujol I, Carbonne A, Barbut F, et al. First cluster of C. difficile toxinotype III, PCR-ribotype 027 associated disease in France: preliminary report. Euro Surveill 2006;11(5):E060504.1. Available from: http://www.eurosurveillance.org/ew/2006/060504.asp\#1

18. Coignard B, Barbut F, Blanckaert K, Thiolet J, Poujol I, Carbonne A, et al. Emergence of Clostridium difficile toxinotype III, PCR-ribotype 027-associated disease, France, 2006. Euro Surveill 2006;11(9):E060914.1. Available from: http://www.eurosurveillance.org/ew/2006/060914.asp\#1

19. Indra A, Huhulescu S, Hasenberger P, Schmid D, Alfery C, Wuerzner R, et al. First isolation of Clostridium difficile PCR ribotype 027 in Austria. Euro Surveill 2006;11(9):E060914.3. Available from: http://www.eurosurveillance. org/ew/2006/060914.asp\#3

20. Kato H, Ito Y, van den Berg R, Kuijper E, Arakawa Y. First isolation of Clostridium difficile 027 in Japan. Euro Surveill 2007;12(1):E070111.3. Available from: http://www.eurosurveillance.org/ew/2007/070111.asp\#3

21. Long S, Fenelon L, Fitzgerald S, Nolan N, Burns K, Hannan M, et al. First Isolation and Report of Clusters of Clostridium difficile PCR 027 cases in Ireland. Euro Surveill 2007;12(4):E070426.1. Available from: http://www. eurosurveillance.org/ew/2007/070426.asp\#3

22. Soes L, Brock I, Persson S, Olsen KEP, Kemp M. Clinical features of Clostridium difficile-associated disease and molecular characterisation of the isolated strains in a cohort of Danish hospitalised patients. 17th European Congress of Clinical Microbiology and Infectious Diseases, Munich, 31 March - 3 April 2007. Abstract \#P762.

23. Health Protection Agency. Mandatory Surveillance of Healthcare Associated Infections Report 2006. Available from: http://www.hpa.org.uk/infections/ topics_az/hai/MandSurvHCAI2006.pdf

24. Department of Health. Surveillance of Clostridium difficile associated disease (CDAD). Available from: http://www.dh.gov.uk/en/Publicationsandstatistics/ Publications/PublicationsPolicyAndGuidance/DH_4118344

25. Brazier J, Patel B, Pearson A. Distribution of Clostridium difficile PCR ribotype 027 in British hospitals. Euro Surveill 2007;12(4):E070426.2. Available from: http://www.eurosurveillance.org/ew/2007/070426.asp\#2

26. Kuijper EJ, van den Berg RJ, Debast S, Visser CE, Veenendaal D, Troelstra A, et al. Clostridium difficile PCR ribotype 027, toxinotype III in The Netherlands. Emerg Infect Dis. 2006;12(5):827-30. Available from: http://www.cdc.gov/ncidod/ eid/voli2no05/05-1350.htm

27. Goorhuis A, Van der Kooi T, Vaessen N, Dekker FW, Van den Berg R, Harmanus C, van den Hof S, Notermans DW, Kuijper EJ. Spread and epidemiology of Clostridium difficile PCR-ribotype 027/toxinotype III in The Netherlands. Clin Infect Dis 2007. In press

28. Vonberg RP, Kuijper EJ, Wilcox MH, Tull P, Gastmeier P, on behalf of the European C. difficile-Infection Control Group and the European Centre for Disease Prevention and Control (ECDC). Infection Control Measures to limit the Spread of Clostridium difficile. Submitted.

Citation style for this article: Kuijper E, Coignard B, Brazier J, Suetens C, Drudy D, Wiuff $C$, and al. Update of Clostridium difficile-associated disease due to PCR ribotype 027 in Europe. Euro Surveill 2007;12(6)[Epub ahead of print]. Available online: http://www. eurosurveillance.org/em/v12n06/1206-221.asp 